\title{
INVESTMENT OF THE FINANCIAL INSTRUMENTS AND THEIR INFLUENCE ON THE EXCHANGE STOCK MARKET DEVELOPMENT
}

\author{
George Abuselidze ${ }^{1}$, Doctor of Economics/ Professor; Anna Slobodianyk ${ }^{2}, \mathrm{PhD}$ in Economics \\ ${ }^{1}$ Batumi Shota Rustaveli State University, Georgia; ${ }^{2}$ National University of Life and Environmental Sciences of \\ Ukraine, Ukraine
}

\begin{abstract}
The formation of recently developed capital markets and expansion of investment alternatives inspires the investors to apply for the challenging investment strategies or search new alternatives for their capital investment. The paper states that among many other investment alternatives, stock market has a number of advantages, namely - the transparent procedure of the exchange market pricing and a variety of trade instruments allowing the potential investor to invest the capital in order to gain profit on a constant basis and in general to create an investment plan completely satisfying the requirements for material security, for financial independence achievement, or for creating own retirement account. The paper reveals that the prospect of profit completely levels risk of loss, despite short-term corrections of securities market and the crisis periods due to the fact that the growing trend proceeds much longer in relation to so-called "waves of corrections" and lasts about 10-12 years, it is in turn connected with business cycles which are overestimated on the stock market acting as the economy indicator in general. It is evident that investment operations in the stock market certainly make profit in the long term, however on the condition of investment portfolio active management it is possible to achieve significantly more profitability if correspondingly they will use speculative operations on shorter periods of time (from 1 week to several months) that is aimed to combine several tools in the trade strategy for maximizing potential profit and minimizing the possible risks. The authors proved that due to options it is possible to reach $30-40 \%$ of annual portfolio profitability on condition of their proper use. Speculative strategies combining purchase and sale of several types of options enable to define the limit of possible risks and potential profit.
\end{abstract}

Key words: Exchange stock market, financial instruments, investments, investment strategy, investment portfolio, option, speculative strategy.

JEL code: D51, D53, E22, E44, G11.

\section{Introduction}

Over the past decade, in many countries of the world, the centralized economy was succeeded by democracy and the system of a free entrepreneurship. New capital markets are emerging and investment alternatives are expanding. Despite all the changes, investors want to gain a large profit, but do not wish to expose themselves to the associated risk, this in turn creates the necessity of application of more sophisticated investment strategies or provokes to search for new alternatives to the usual options in order to invest their capital. Investors often worry about the risk of losing their entire investment. Closures of exchange-traded funds, like the closures of mutual funds, are not uncommon. Anywhere from 50 to 80 exchange-traded funds close each year (Madhavan, 2016).

An investor can thoughtlessly reject important classes of investment assets, bonds or stocks, even if this particular asset class plays an important role in the development of the best strategy for achieving the goals. Return on assets and risk assessment, which is used both in ordinary and alternative investments policy is to be perspective as well as effective and reflect connection of basic economic risks with regard to assets (Abuselidze et al., 2018). Therefore, the structure of the portfolios of many investors precisely reflects their level of comfort and investment advantages, but is far from the necessary achievement of the stated financial objectives. The challenges of the 21st century stock market require from investors or investment advisers something more than a current assessment of a client' state of affairs, namely the development of corresponding strategies, because in most cases the client does not have conceptual knowledge or sufficient competence to understand the necessity to follow the received recommendations in his/her own interests. The rational use of

\footnotetext{
${ }^{1}$ Corresponding author. E-mail address: abuseri@mail.ru, george.abuselidze@bsu.edu.ge ; http://orcid.org/0000-0002-5834-1233

2 E-mail address: slobodyanikann@gmail.com ; http://orcid.org/0000-0001-6437-0033
} 
resources and a sufficient level of education promotes a potential investor to create a sTable source of the passive return through investment operations carried out on the stock market.

The actuality of the article is justification of the value of the investment operations and the study of their state and development. The preference is given to the securities instead of the practical means of investing (Abuselidze G., 2013). The investment process ensures the stability of the securities market which plays a significant role in the development of the financial market in general, which in turn is an indicator of the state of the entire economy. According to Bayadyan and Baghdasaryan $(2017$, p.92) the development of the capital market is an important factor affecting the potential for economic development and sustainable economic growth in the EAEU countries. The term "Capital Market" refers only to financial capital. That is why Capital Markets are always financial markets, not subjective markets (Juurikkala, 2012, p. 88). According to Khan et al. (2018) the stock market is a strong indication for economic conditions of a country. Stock exchange provides a neutral ground for brokers and companies to invest. Mobilization of investments is one of the actual leverages for progress of national economy (Abuselidze, 2018).

\section{Research results and discussion}

There many reasons encouraging a person to make investment, the most important being the necessity for a large amount of money to ensure his/her old age. Our investments form the basis promoting our future purchasing ability. Unsuccessful investments of course can lead to negative return and decrease future purchasing ability.

In the broadest sense, the word "investment" is the investment (attraction) of own capital into investment of the objects in order to obtain the long term profit. According to the interpretation of William Sharpe, a professor of Stanford University, an investment is a rejection of a certain value of an asset just for the benefit of its future greater potential value. He also interprets the concept of investment as follows-a set of procedures encouraging an investor to make a decision about the asset investment, how large the investment should be and the specific moment they should be carried out (Sharpe et al., 2001).

The investment process begins with the investment plan preparation stating the objectives and describing the strategy for their achievement. Before directing free funds to fulfil your plan, you should be assured that there is a reserve fund intended to cover unforeseen expenses, for example, in case of emergency medical care, job loss, damage or loss of your own property. It is advisable to invest the funds of your own reserve fund into liquid assets that can be quickly converted into money in case of necessity without significant losses. Liquid assets include all money market instruments and bank deposits (Rezgo, Ketova, 2005).

By creating a reserve fund, you can start the formation of a long term investment.

5 steps to create an investment plan:

- define your financial objectives;

- distribute your assets;

- - develop an investment strategy;

- choose investment tools;

- $\quad$ evaluate your investment portfolio. 


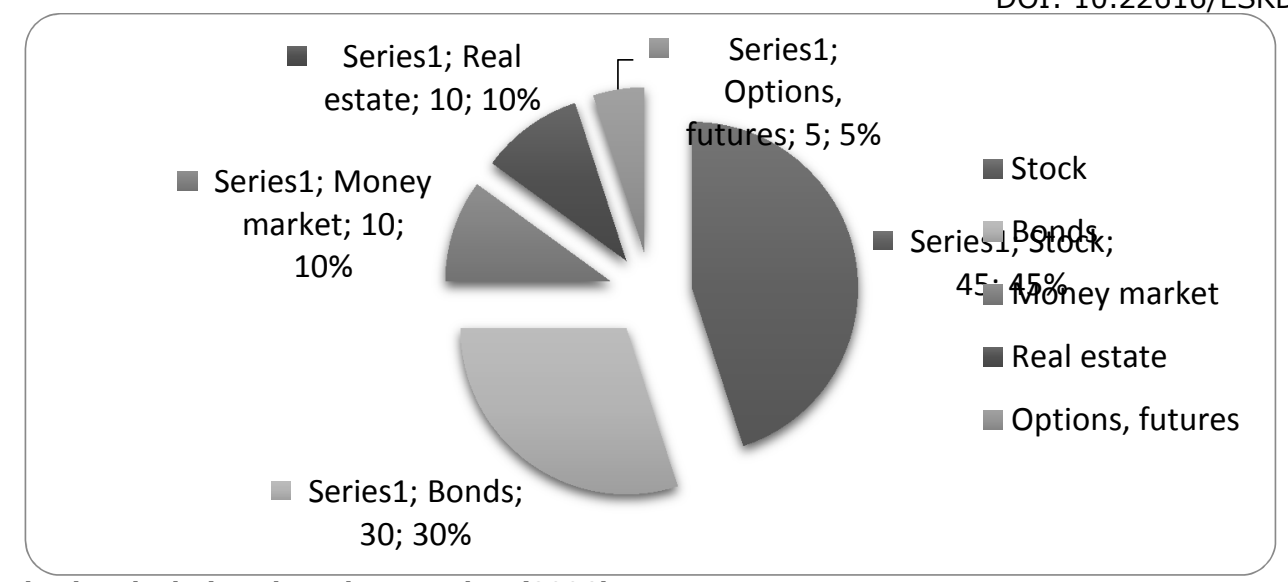

Source: author's calculations based on Faerber (2006)

Fig. 1. An example of the assets distribution in the portfolio

Investors having more time (30 years and more) can invest in shares and other assets growing in the price. Investors of pre-retirement age should direct a considerable part of their capital into bonds or other risk-free or low-risk assets to maintain their standard of living and a smaller portion of the capital into riskier assets, such as stocks in order to provide the growth of the portfolio. According to Lettau and Madhavan (2018, p. 151), exchange-traded products provide exposure to a wide range of asset classes (for example, equities, fixed income commodities, and currencies), strategies (for example, passive index, model-based, and active), and regions.

If an investor is focused on the long-term ownership of an asset, then he should give preference to passive investment. In turn, an active investment strategy is the implementation of trading operations on a permanent basis throughout the investment period to generate more return compared to the average market indicators. The choice of investment strategy depends on market efficiency assessment - that is, how efficiently the stock and bond markets handle information affecting the value of assets. The choice of investment strategy depends on market performance evaluation - that is, how effectively the stock and bond markets process information affects the value of assets.

Passive investors choose a diversified portfolio including shares related to various sectors of the economy, such as the technology sector, industrial, financial raw materials and many others. An active investor forms a portfolio, evaluating the fundamental indicators of companies from various sectors of the economy, in order to find and purchase undervalued shares and then sell them after reaching their fair value price (Markowitz, 1952).

Liquid assets can be quickly converted without significant losses when converted into money. These include: US Treasury bills, commercial bills, bank acceptances, money market mutual funds, short-term deposit certificates, bank deposits. They are ideal for investments aimed at creating a reserve fund. It is worth to evaluate your portfolio periodically since all the changes that occur in life may create the need of amendments to the current structure of the investment portfolio. In addition, economic and market fluctuations can affect asset allocation. You should also take into account the changes that occur in companies whose securities are in your portfolio, since such changes can lead to changes in the market value of the shares (Brinson et al., 1995).

In order to see the clear example of the stock market development, it is better to focus on the United States. The American stock market is the world leader in this industry and therefore it acts as a driving force if the markets begin to grow or fall into crisis. 
The profitability of the NASDAQ technology index is higher than the profitability of $S \& P$ and DowJones. This is due to the fact that this index includes shares of the largest non-financial companies, a significant share of which is occupied by technology companies, showing higher than the average market return from the beginning of the 21st century. However, the high return of this index is accompanied by its greater volatility, that is, the level of risk/return is higher here than in $S$ $\& \mathrm{P}$ and DowJones.

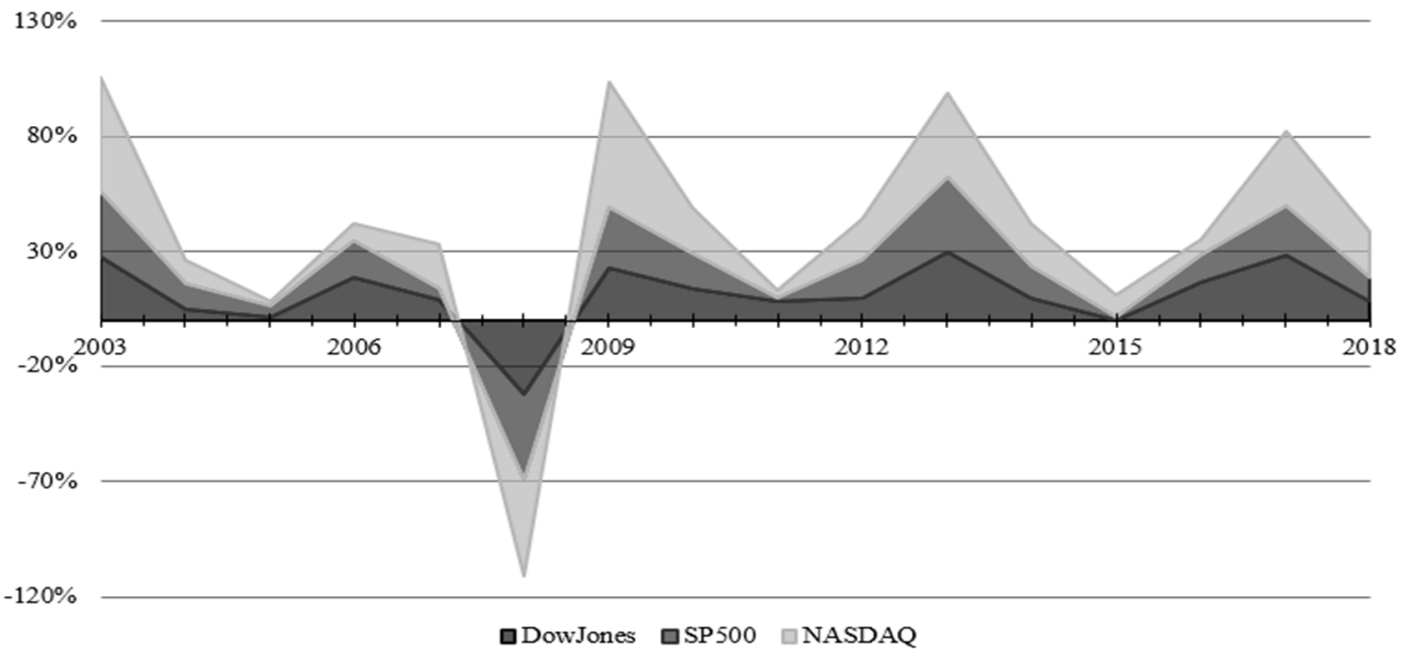

Source: author's calculations based on Futures industry association (2018)

Fig. 2. Profitability of the major stock indexes of the USA

The results of research, made on the factual basis of the American stock market, showed that there are different interdependencies between returns and risks of financial assets at different investment horizons which differ significantly in terms of types of assets (stocks, bonds, treasury bills), as well as duration of the investment horizon. The studies of Zakharkin et al. (2018) show that with an increase of the investment horizon, the volatility of stocks significantly decreases, making them more attractive for investors as compared with bonds. The volatility of European stock markets was researched by B. Harrison, W. Moore (2012), D. Gjika, R. Horvath (2013), J. Okičić (2014), A. Hepsag (2016), B. Yavas and L. Dedi (2016).

Stock markets provide a better platform to people as compared to traditional banking investments. People can invest their money and can get a huge profit if they invest sensibly. According to Khan et al. (2018), stock investments return more profit than bank deposits and bonds. Bonds occupy an equally important niche in the securities market. The use of bonds is associated with lower risks than when using bank lending. The company undertakes to pay interest and the body of the loan until the bankruptcy moment. If company affairs go wrong, the investor will be affected by the reduction in the value of shares and the termination of dividend payments. Payments on the bonds are made until the company bankruptcy declaration. Due to the high interest payment guarantee, their returns are lower in stocks. An investor, wanting to gain a greater profit than from a bank deposit or bond purchase, boldly declares that stocks are a suiTable tool for making profits. The ratio of the risk and return allows him to make a long term profit.

After drawing up the financial plan, the investor needs to develop his investment portfolio (Fig. 3). Portfolio formation depends on your preferences and risk inclination. So, there are 3 main types of investment portfolios depending on the risk level of the investor:

- - Conservative;

- - Moderate;

- $\bullet$ Aggressive (highly risky). 
The first step is to create an investment portfolio. The name "portfolio" implies choosing a certain number of trading instruments for mutual compensation of possible risks and an increase in potential return (stocks, bonds, indices, ETFs).

The investor can combine a set of instruments, as well as their share in the portfolio structure, depending on his/her personal preferences and risk inclination.

The second stage is portfolio diversification (asset allocation). For example, if you created it exclusively from stocks, then you should select companies from different sectors of the economy:

- finance;

- pharmaceutics;

- technology sector;

- services sector;

- power system,

- others.

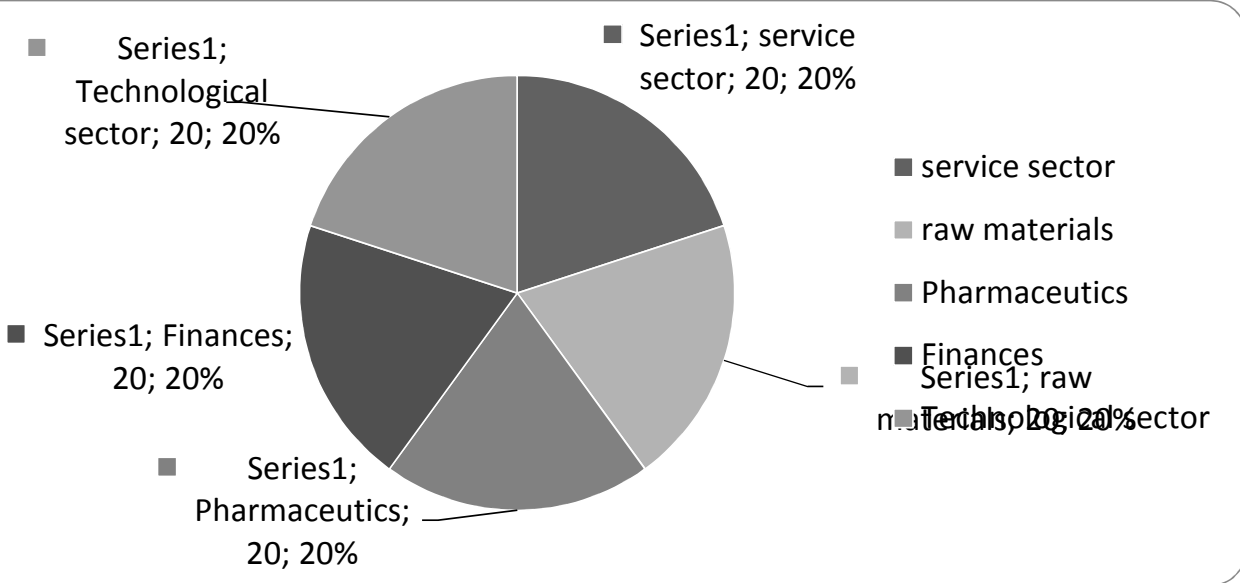

Source: author's calculations based on ElIman (2011).

Fig. 3. Example of a diversified portfolio

By investing in stocks, adhering to the strategy "buy and hold", you can gain profit from the dividend paid by the company or from the value growth of the shares you purchased in the long term. However, the options for making money in the securities market do not finish there. An investor can gain much more from investments if he combines several trading instruments in his investment strategy.

One of such strategies is "Covered Call" - a covered Call option. This trading strategy combines the purchase of shares for long-term ownership and the parallel sale of "Covered Call" options on these shares. Options in money (call option price is below the current price of the underlying asset) can be compared with an insurance policy (Kratter, 2015).

Although this is a free insurance policy (paid by the buyer of the option), it somewhat levels the possibility of increasing the value of the shares, but provides an additional "airbag" when it decreases (Fig. 4). Situations favourable for the potential sale of options in money:

1. extremely volatile market;

2. technical analysis of stocks shows mixed performance;

3. rising, but unsTable schedule. 


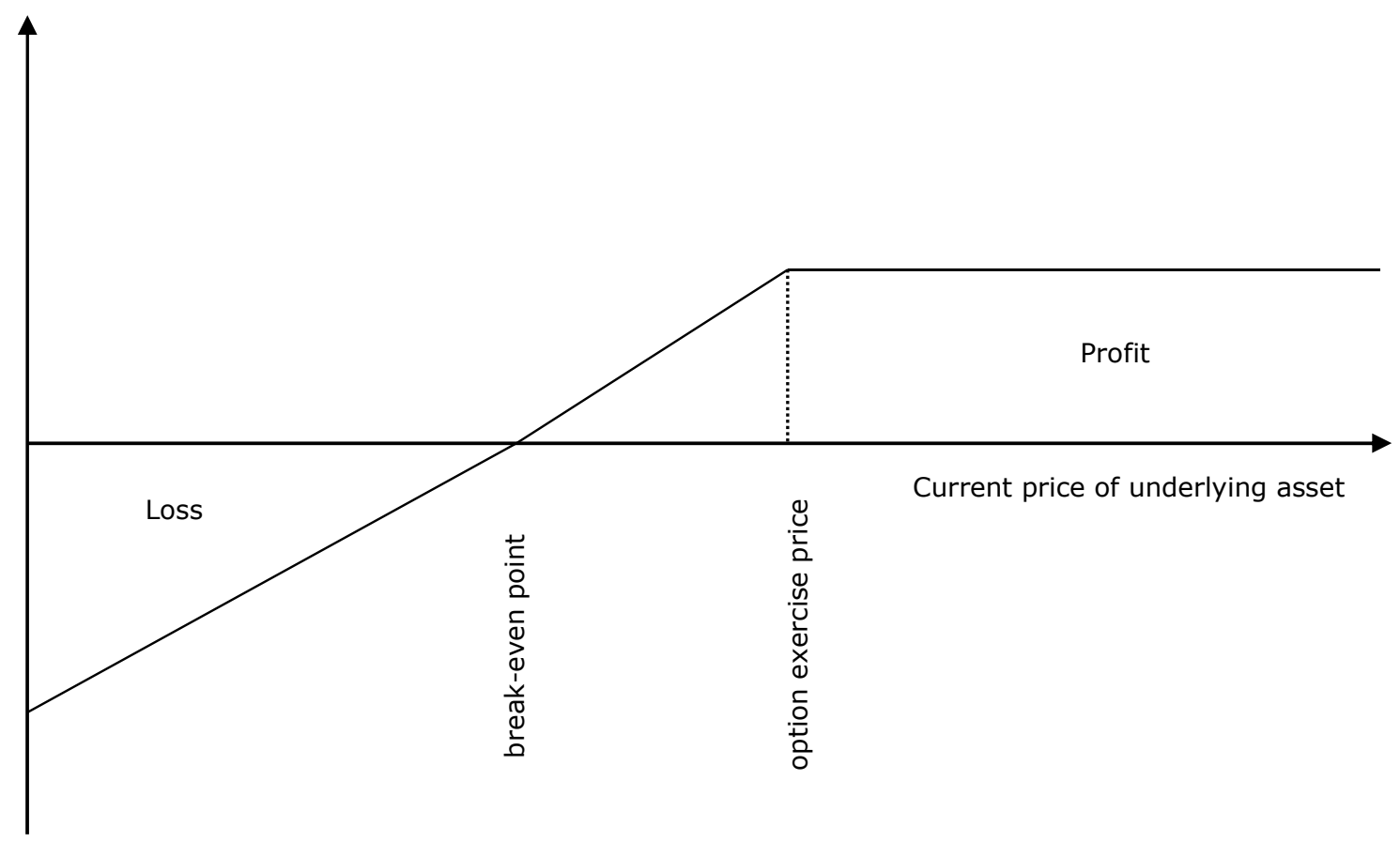

Source: author's calculations based on Cohen (2005)

Fig. 4. Selling a call option in „money"

The reasons for selling covered options are as follow.

1) Selling a call option is the most profiTable of all the moderately risky strategies that investors use in the stock market.

2) Selling call options effectively works under any market conditions, it can be bullish, bearish or neutral trend. But it is worth remembering, if the market is directed at a certain trend, then with a strong uptrend it is better to own a share, with a strong downtrend it is better to change the asset at all, the best option for this strategy is a low volatile bullish market.

3) You can generate profits without much effort. All you need is a computer, appropriate skills, discipline, and a spirit for success.

4) You can efficiently use the profit. Funds received from the sale of options are deposited to your account on the day of the transaction or the next - depending on the working conditions with the broker.

5) You can control the ratio of profit and risk through the use of exit strategies. There are many ways of control when dealing with the sale of options, and you can use all their advantages.

6) You can create a breakeven point below the current price of the asset you own. We can recall an example of using an option sales strategy. The premium insurance is a "safety cushion" for your assets in case of a small drawdown.

7) You, as the seller of the options and the owner of the shares, reserve the opportunity to receive dividends.

8) Passive portfolio management occasionally, provides a return above the average market. Selling Circles gives you the opportunity to beat the market.

Investment operations on the stock market certainly bring long term profit. However, if you actively manage your investment portfolio, you can achieve a significantly higher average return by using speculative operations on shorter time intervals (from 1 week to several months) in parallel, 
which aims to combine several instruments in your trading strategy to maximize potential returns and minimize possible risks. A clear example of such a combination is the purchase of shares and bonds as two instruments mutually compensating risks due to their negative correlation as well as the parallel sale of Call options on the acquired assets with the recommended deadlines of 20-30 days. This strategy will allow to use the whole capital and at the same time increase the potential return of the investment portfolio, and due to the negative correlation between asset classes such as stocks and bonds, as well as due to the functionality of options, the investor has the opportunity to manage its risks.

\section{Conclusions, proposals, recommendations}

1) Portfolio Structure of many investors accurately reflects their level of comfort and investment advantages, but is far from the one that is necessary to achieve the stated financial objectives. With the rational use of resources and a sufficient level of education, a potential investor can create a sTable source of the passive return through investment operations carried out on the stock market.

2) The investment process begins with an investment plan stating the objectives and describing a strategy for their achievement. Before directing free funds to implement your plan, you should be sure that there is a reserve fund intended to cover unforeseen expenses that arise, for example, in case of emergency medical care, job loss, damage or loss of your own property. It is advisable to invest your own reserve fund into liquid assets, that can be quickly converted into money in case of necessity without significant losses.

3) Passive investors choose a diversified portfolio, that is, one that includes stocks related to various sectors of the economy, such as the technology sector, industrial, financial raw materials, among others. An active investor forms a portfolio, evaluating the fundamentals of companies from different sectors of the economy, in order to find and buy undervalued stocks and then sell them after reaching their fair value price.

4) After drawing up the financial plan, the investor develops his investment portfolio. Portfolio formation depends on the preferences and risk inclination, the choice of a certain number of trading instruments for mutual compensation of possible risks and an increase in potential return (stocks, bonds, indices, ETFs).

5) By investing in stocks, adhering to the strategy of "buy and hold", you can gain profit from the dividends paid by the company or from the increased price of the long term purchased shares. However, the options for making money in the securities market do not finish there. An investor can get much more if he combines several trading instruments in his investment strategy. One of these strategies is "Covered Call" - Covered Call Option. This trading strategy combines the purchase of shares for the long-term ownership and the parallel sale of Call options on these shares. In addition, a strong advantage of options among other stock instruments is that it is not necessary to anticipate the future price trend, you can gain profit in any market conditions, turning the mathematical expectation of the options return in your favour.

\section{Bibliography}

1. Abuselidze, G., Beridze, L. 2018. The Role of Alternative Investments in the Development of Capital Markets: in Terms of the Transformation of Georgia with the EU. In Stanikkova, M., L. Melecky, E. Kovarova and K. Dvorokova (eds.). Proceedings of the 4th International Conference on European Integration 2018. Ostrava: VŠB - Technical University of Ostrava, 2018, pp. 29-41. ISBN 978-80-248-4169-4. ISSN 2571029X.

2. Abuselidze, G. (2018). Georgia's capital market: Functioning Problems and Development Directions in Association with EU. Journal of Applied Economic Sciences, Volume XIII, Winter, 7(61). 
3. Abuselidze, G. (2013). Undeveloped equity market as a factor preventing foreign investments (Georgia as an example). Ekonomichnyy analiz, 12(1).

4. Bayadyan, A., Baghdasaryan, A. (2017). Problems of Development and Integration of the Securities Market in the Countries of the EAEU. VESTNIK MEZHDUNARODNYKH ORGANIZATSII-INTERNATIONAL ORGANISATIONS RESEARCH JOURNAL. 12(4), pp. 91-108.

5. Brinson, G. P., Hood, L. R., Beebower, G. L. (1995). Determinants of portfolio performance. Financial Analysts Journal, 51(1), pp. 133-138.

6. Cohen, G. (2005), The Bible of Options Strategies, Pearson Education, New Jersey, USA.

7. Ellman, A. (2011). Complete Encyclopaedia for Covered Call Writing, ISBN: 978-1937183066.

8. Faerber, E., (2006). All About Investing: The Easy Way to Get Started https://www.litmir.me/bd/?b=431030.

9. Futures industry association (2018), «exchange volume» available at: https://fia.org/categories/exchangevolume (accessed ).

10. Gjika, D., Horvath, R. (2013, July). Stock market comovements in Central Europe: Evidence from the asymmetric DCC model. Economic Modelling, p.33, pp. 55-64. https://doi.org/10.1016/j.econmod.2013.03.015.

11. Harrison, B., \& Moore, W. (2012). Forecasting Stock Market Volatility in Central and Eastern European Countries. Journal of Forecasting, 31(6), pp. 490-503. https://doi.org/10.1002/for.1214.

12. Hepsag, A. (2016). Asymmetric stochastic volatility in central and eastern European stock markets. Theoretical and Applied Economics, 607(2), pp. 135-144. Retrieved from http://store.ectap.ro/articole/1187.pdf.

13. Juurikkala, O. (2012). The Behavioural Paradox: Why Investor Irrationality calls for Lighter and Simpler Financial Regulation, Fordham Journal of Corporate \& Financial Law, Vol. XVIII, pp. 33-93.

14. Khan, U., Aadil, F., Ghazanfar, M., Khan, S., Metawa, N., Muhammad, K., ... Nam, Y. (2018). A Robust Regression-Based Stock Exchange Forecasting and Determination of Correlation between Stock Markets. Sustainability, 10(10), 3702. doi.org/10.3390/su10103702.

15. Kratter, M.R. (2015). Covered Calls Made Easy: Generate Monthly Cash Flow by Selling Options Kindle Edition by Matthew R. Kratter.

16. Lettau, M., Madhavan, A. (2018). Exchange-Traded Funds 101 for Economists, Journal of Economic Perspectives, 32(1), pp. 135-154. DOI: 10.1257/jep.32.1.135.

17. Madhavan, A. (2016). Exchange-Traded Funds and the New Dynamics of Investing. Oxford University Press: New York, NY.

18. Markowitz, H. (1952). Portfolio selection. The journal of finance, 7(1), pp. 77-91.

19. Okičić, J. (2014). An Empirical Analysis of Stock Returns and Volatility: The Case of Stock Markets from Central and Eastern Europe. South East European Journal of Economics and Business, 9(1), 7-15. https://doi.org/10.2478/jeb-2014-0005.

20. Rezgo, G. Y., Ketova, I. A. (2005). Birzhevoe delo [Exchange business]. Moscow: Finansyi i statistika.

21.Sharpe, W. F., Alexander, G. J., Bailey, J. (2001). Investitsii [Investments]. Moscow, INFRA-M Publ, 1035. (Alexander, G. J., Sharpe, W. F., \& Bailey, J. V. (2001). Fundamentals of investments. Pearson College Division.).

22. Yavas, B. F., Dedi, L. (2016). An investigation of return and volatility linkages among equity markets: A study of selected European and emerging countries. Research in International Business and Finance, 37, pp. 583-596. https://doi.org/10.1016/j.ribaf.2016.01.025.

23. Zakharkin, O., Zakharkina, L., Antoniuk, N. (2018). A comparative analysis of stock market volatility depending on investment time horizon. ECONOMIC ANNALS-XXI, 167(9-10), pp. 49-52. https://doi.org/10.21003/ea.V167-10. 